\title{
PENENTUAN JUMLAH OPERATOR OPTIMAL DENGAN METODE SIMULASI
}

\author{
SATYA SUDANINGTYAS \\ Jurusan Teknik Industri, Fakultas Teknik, Universitas Muhammadiyah Malang \\ Laman: satya.sudaningtyas@gmail.com
}

\begin{abstract}
ABSTRAK
Penelitian ini dilakukan untuk menerapkan metode simulasi pada suatu sistim pelayanan dalam rangka menentukan jumlah operator yang optimal agar performansi sistim tersebut dapat lebih baik. Performansi suatu sistim dapat ditinjau dari banyak hal. Salah satunya adalah ditinjau dari waktu tunggu konsumen. Dalam penelitian ini, simulasi dilakukan terhadap sistim pelayanan saat ini (sistim existing) dan sistim pelayanan skenario usulan. Hasil penelitian menunjukkan bahwa skenario usulan berhasil menurunkan waktu tunggu konsumen secara signifikan, yaitu sebesar 14,75 menit.
\end{abstract}

Kata kunci: penentuan jumlah operator, simulasi, waktu tunggu

\begin{abstract}
This study was conducted to apply simulation method on a service system in order to determine the numbers of optimum operator so that the performance of the system was better. The performance of system could be observed from various aspects. One of them was consumer waiting time. In this study, simulation was conducted on the existing service system and the proposed scenario service system. The result showed that the proposed scenario service system was succeed in decreasing consumer waiting time significantly at 14,75 minutes.
\end{abstract}

Key words: determination of numbers of operator, simulation, waiting time

\section{PENDAHULUAN}

Performansi suatu sistim pelayanan biasanya dikaitkan dengan kepuasan konsumen karena kepuasan konsumen merupakan hal terpenting pada suatu sistim pelayanan. Kepuasan konsumen dapat ditinjau dari berbagai hal, misalnya kualitas pelayanan yang diberikan, keramahan operator, ketepatan operator dalam melayani konsumen, serta kecepatan operator dalam melayani konsumen. Tidak pernah ada konsumen yang mau menunggu lama untuk dilayani ataupun untuk mendapatkan barang yang diinginkan. Karenanya, diperlukan suatu metode kerja yang tepat agar waktu tunggu konsumen dapat dikurangi. Metode kerja meliputi bagaimana kerja dilakukan. Selain itu, pada sistim pelayanan yang didominasi oleh tenaga kerja manusia (misalnya apotek, rumah sakit, dan lain-lain). Maka pelayanan ditentukan oleh jumlah operator yang ada. Karenanya, ketepatan jumlah operator merupakan salah satu hal penting yang secara tidak langsung mempengaruhi kepuasan pelanggan.

Ada banyak penelitian tentang penentuan jumlah tenaga kerja optimal. Penelitian yang telah dilakukan oleh Khumairoh (2009) menggunakan metode workload analysis untuk mengevaluasi jumlah operator optimal. Akan tetapi, pada penelitian tersebut tidak dapat diketahui apakah jumlah operator optimal yang diusulkan benarbenar dapat memperbaiki sistim pelayanan. Penelitian ini dilakukan untuk menerapkan skenario usulan penelitian terdahulu tersebut dengan menggunakan simulasi. Simulasi dipilih karena dapat menunjukkan performansi sistim pelayanan sebelum menerapkannya ke sistim nyata terlebih dahulu.

Pada penelitian ini, performansi sistim pelayanan akan ditinjau dari waktu tunggu konsumen. Karena penelitian terdahulu menghasilkan dua skenario usulan, terkait dengan perbedaan jumlah dan metode kerja operator, maka simulasi akan dilakukan pada kedua skenario usulan tersebut dan terhadap sistim existing. Hal ini dilakukan untuk membandingkan performansi sistim pelayanan sehingga akan dapat dipilih skenario usulan mana yang lebih baik dari kondisi existing. Dengan simulasi tidak hanya dapat diketahui waktu tunggu konsumen, tetapi juga utilitas operator. 


\section{METODE}

Penelitian ini dilakukan di Apotek di Rumah Sakit X. Untuk menentukan jumlah operator optimal dengan metode simulasi, penelitian dimulai dengan identifikasi gambaran dan komponen sistim. Pemodelan merupakan langkah lanjutan setelah gambaran dan komponen sistim diidentifikasi. Dalam penelitian ini, pemodelan dilakukan pada software Arena. Selanjutnya, dilakukan verifikasi dan validasi. Verifikasi dilakukan dengan menggunakan fasilitas pemeriksaan yang ada pada Arena, sedangkan validasi dilakukan dengan membandingkan output simulasi sistim existing dan sistim real. Bila model simulasi valid, maka 2 skenario usulan diterapkan pada model simulasi. Dari hasil simulasi sistim existing, skenario 1 , dan skenario 2, maka dapat dilakukan perbandingan performansi sistim sehingga dapat ditentukan jumlah operator optimalnya.

\section{HASIL DAN PEMBAHASAN}

\section{Gambaran dan Komponen Sistim}

Apotek di Rumah Sakit X ini melayani resep dokter maupun pembelian dari luar. Resep diterima di bagian penerimaan untuk kemudian dilakukan pencatatan informasi. Pengecekan ketersediaan obat kemudian dilakukan terhadap resep tersebut serta dilakukan perhitungan total harga. Selanjutnya dilakukan transaksi uang serta pemberian nomor antrian. Peracikan obat, peng-copy-an resep, serta pengecekan item dilakukan setelah uang diterima. Kemudian, obat diserahkan ke konsumen dan dilakukan pemberian penjelasan mengenai aturan minum obat. Untuk pembelian dari luar, setelah konsumen diterima di bagian penerimaan untuk ditanyai obat yang akan dibeli dan dilakukan pengecekan ketersediaan obat serta harganya, dilakukan pengambilan obat. Selanjutnya, obat diserahkan ke konsumen dan dilakukan transaksi uang. Apotek ini memberikan pelayanan selama 24 jam sehingga terdapat 3 shift pelayanan. Akan tetapi, karena keterbatasan waktu penelitian, penelitian dilakukan terhadap 2 shift saja, yaitu shift pagi dan shift sore.

Komponen sistim terdiri atas entity, atributte, resources atau operator, activity, dan control (Partiwi dkk., 2009). Entity merupakan sesuatu yang dikenai activity dalam sistim. Dalam sistim pelayanan penjualan obat-obatan ini, konsumen dengan resep (pasien) dan konsumen tanpa resep (umum) merupakan entity. Resource adalah sesuatu yang melakukan activity dalam sistim. Pada sistim ini, resource-nya adalah para operator yang melayani penjualan obat-obatan, yang berjumlah 5 orang. Activity merupakan kegiatan interaksi antar komponen sistim. Dalam sistim ini, activity-nya yaitu penerimaan awal, pengecekan ketersediaan obat dan harga, pemberian nomor antrian dan penerimaan uang, peracikan obat dan pemberian label, pengcopy-an resep, pengecekan item obat, pemberian obat dan penjelasan aturan minum, pengambilan obat, serta penyerahan obat dan transaksi uang. Control merupakan suatu hal yang menjelaskaan bagaimana, apa, dan kapan aktivitas dilakukan. Dalam sistim ini, control-nya adalah dalam sehari proses dilakukan antara pukul 07.00-22.00 serta satu shift berlangsung selama 8 jam. Selain itu, disiplin pelayanannya bersifat first come, first serve, yang berarti entitas yang datang pertama akan dilayani terlebih dahulu (Siswanto, 2007).

\section{Pemodelan Simulasi}

Tahap ini dimulai dengan plotting distribusi waktu antar kedatangan dan waktu setiap operasi. Berdasarkan plotting di input analyzer, maka dapat diketahui bahwa waktu antar kedatangan konsumen dengan resep (pasien) pada shift 1 berdistribusi poisson $(15,9)$ menit dan pada shift 2 berdistribusi poisson $(15,2)$ menit. Sedangkan waktu antar kedatangan konsumen tanpa resep (umum) pada shift 1 berdistribusi poisson $(41,6)$ menit dan pada shift 2 berdistribusi $(86,5)$ menit.

Kemudian, dapat diketahui juga bahwa waktu proses penerimaan awal berdistribusi normal $(14,2$; 1,67) detik, waktu proses pengecekan ketersediaan obat dan harga berdistribusi normal $(85,9 ; 24,8)$ detik, waktu proses pemberian nomor antrian dan penerimaan uang berdistribusi normal $(23,8 ; 5,4)$ detik, waktu proses peracikan obat dan pemberian label berdistribusi normal $(12,1 ; 2,53)$ menit, waktu proses peng-copy-an resep berdistribusi normal $(8,88 ; 1,85)$ menit, waktu proses pengecekan item obat berdistribusi normal $(32,3 ; 5)$ menit, waktu proses pemberian obat dan penjelasan aturan minum berdistribusi normal $(60,8 ; 4,15)$ detik, waktu proses pengambilan obat berdistribusi normal $(71,3 ; 6,83)$ detik, serta waktu proses penyerahan obat dan transaksi uang berdistribusi normal $(77,6 ; 8,35)$ detik.

Pada sistim ini, terdapat 2 entitas, yaitu entitas resep dan umum, dan 2 shift, yaitu shift pagi (shift 1) dan shift siang (shift 2). Karenanya, digunakan 4 modul create dan 1 modul decide. Pemodelan pada software Arena pada kondisi ini dapat dilihat di Gambar 1.

Pembedaan entitas dilakukan dengan membedakan jenisnya. Dalam modul create, hal tersebut dilakukan pada pilihan entity tipe. Karena shift 1 berlangsung selama 8 jam, maka first creation 


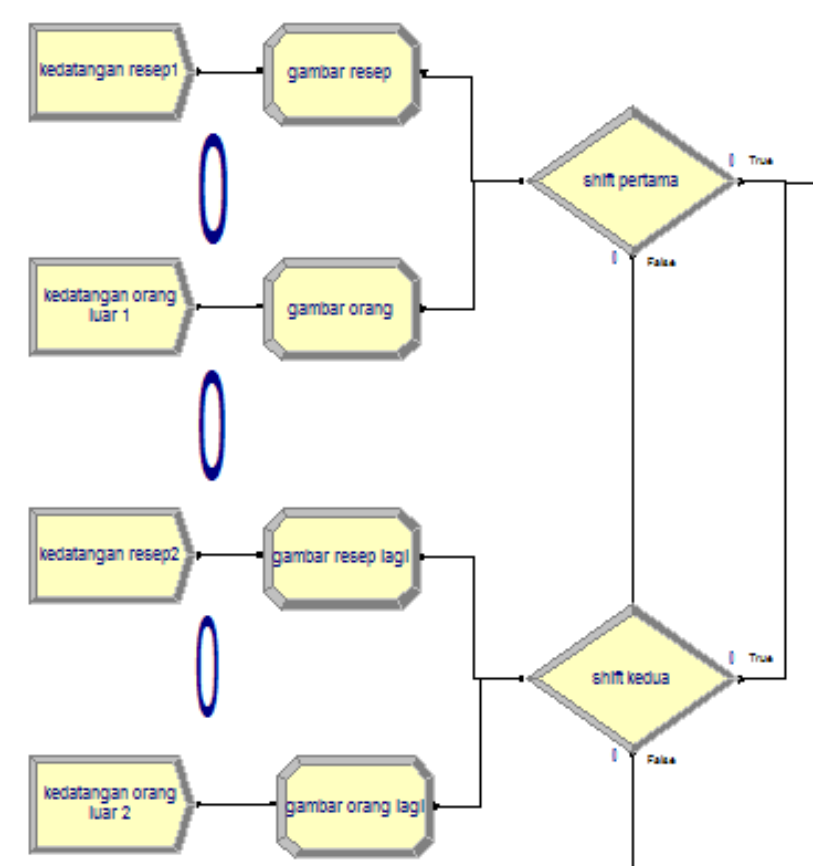

Gambar 1. Pemodelan Kedatangan di Shift 1 dan Shift 2

pada modul create untuk shift 1diisi dengan angka 0,0 , artinya, resep akan mulai datang pada menit ke-0. Pemodelan ini digambarkan pada Gambar 2. Selain itu, digunakan modul decide untuk membatasi kedatangan entitas pada shift 1. Expression yang digunakan sebagai penentu keputusan pada modul decide ini adalah TNOW $<=8$, artinya jika waktu running simulasi masih kurang dari dan sama dengan 8 jam, maka semua entitas yang masuk adalah termasuk shift 1 . Demikian juga pada modul decide untuk shift 2 , expression yang digunakan sebagai penentu keputusan adalah $\mathrm{TNOW}<=16$, artinya jika waktu running simulasi masih kurang dari dan sama dengan 16 jam, maka semua entitas

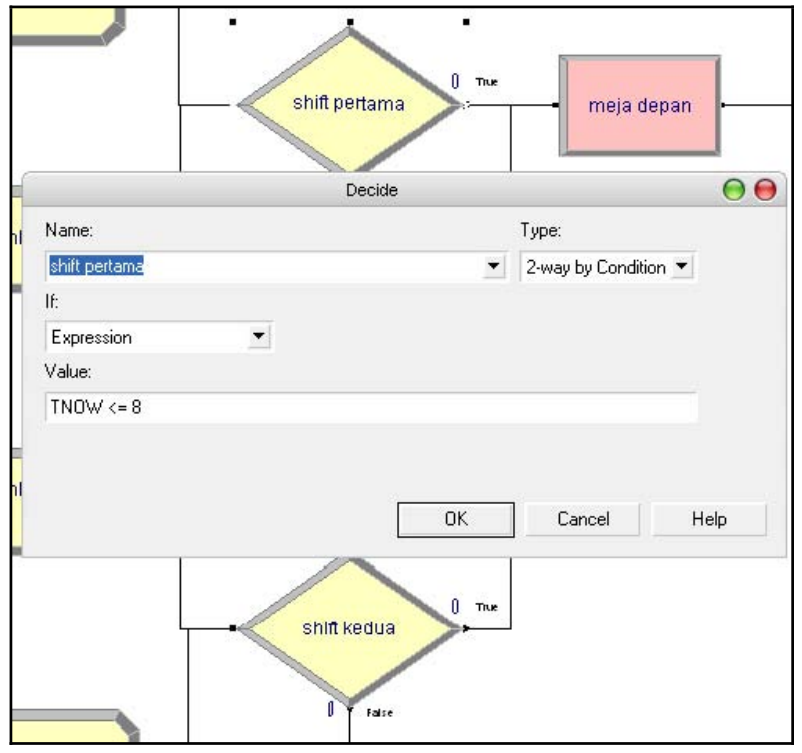

Gambar 3. Pemodelan untuk Membedakan Shift 1 dan Shift 2

yang masuk adalah termasuk shift 2 . Pemodelan untuk kondisi ini digambarkan pada Gambar 3.

Modul yang digunakan untuk menggambarkan proses yang terjadi pada sistim adalah modul process. Pada proses pemberian obat, misalnya, dapat dilihat bahwa action yang digunakan adalah seize delay release yang berarti bahwa dalam proses tersebut dilakukan penerimaan, perlakuan, serta pelepasan entitas sekaligus oleh operator yang sama. Ada kalanya, pada satu proses, action yang digunakan adalah seize ataupun delay saja ataupun delay release saja. Biasanya penggunaan action-action ini berurutan. Hal ini berarti meskipun entitas mengalami beberapa proses, akan tetapi operator yang menanganinya adalah sama. Pemodelan untuk kondisi ini digambarkan pada Gambar 4.

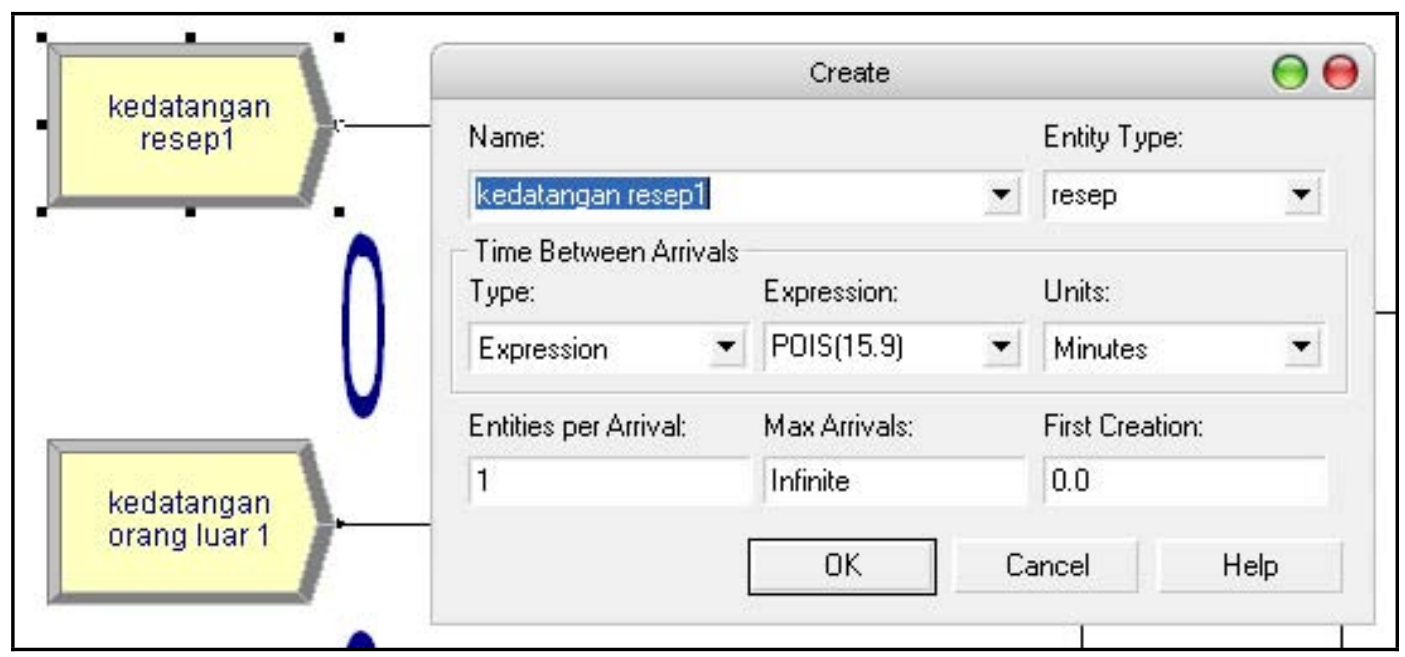

Gambar 2. Pemodelan Kedatangan di Shift 1 


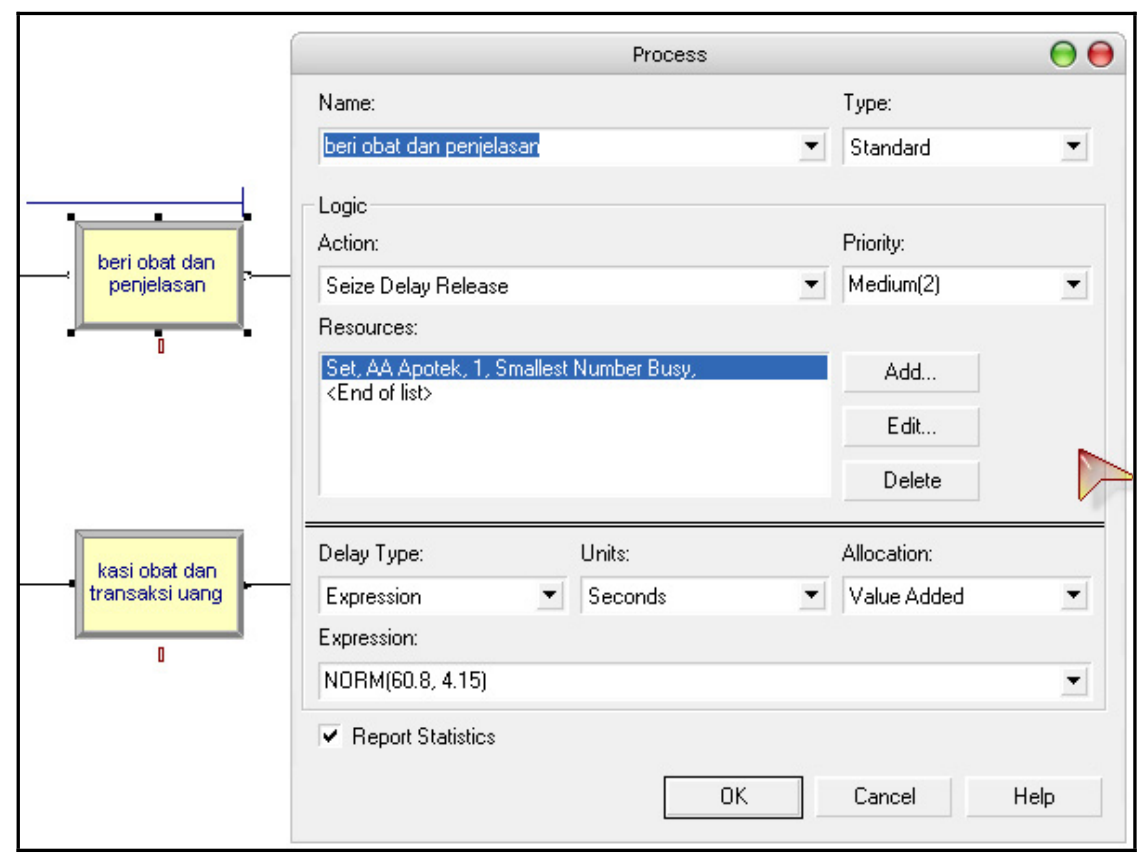

Gambar 4. Penggambaran Aktifitas dengan 1 Resources

Di model simulasi existing, pelayanan dilakukan berdasarkan kapasitas terpakai operator. Jika kapasitas terpakai operator masih penuh, maka entitas yang masuk harus menunggu. Untuk itu, diperlukan modul decide dengan expression penentu keputusannya adalah "2a racik obat dan beri label. $\mathrm{WIP}==0$ ", yang artinya entitas akan masuk ke proses "2a racik obat dan beri label" ketika tidak ada work in process di proses tersebut. Jika masih ada work in process, maka entitas akan masuk ke proses " $2 \mathrm{~b}$ racik obat dan beri label". Pemodelan untuk kondisi ini dapat dilihat pada Gambar 5.

Dalam simulasi ini juga digunakan modul hold dan signal. Modul hold digunakan untuk menggambarkan keadaan menunggu yang dialami oleh entitas, sedangkan signal digunakan sebagai penanda keadaan menunggu telah usai. Kedua modul ini digunakan untuk mengakomodasi kemungkinan resep harus menunggu dilayani ketika semua operator sedang busy.

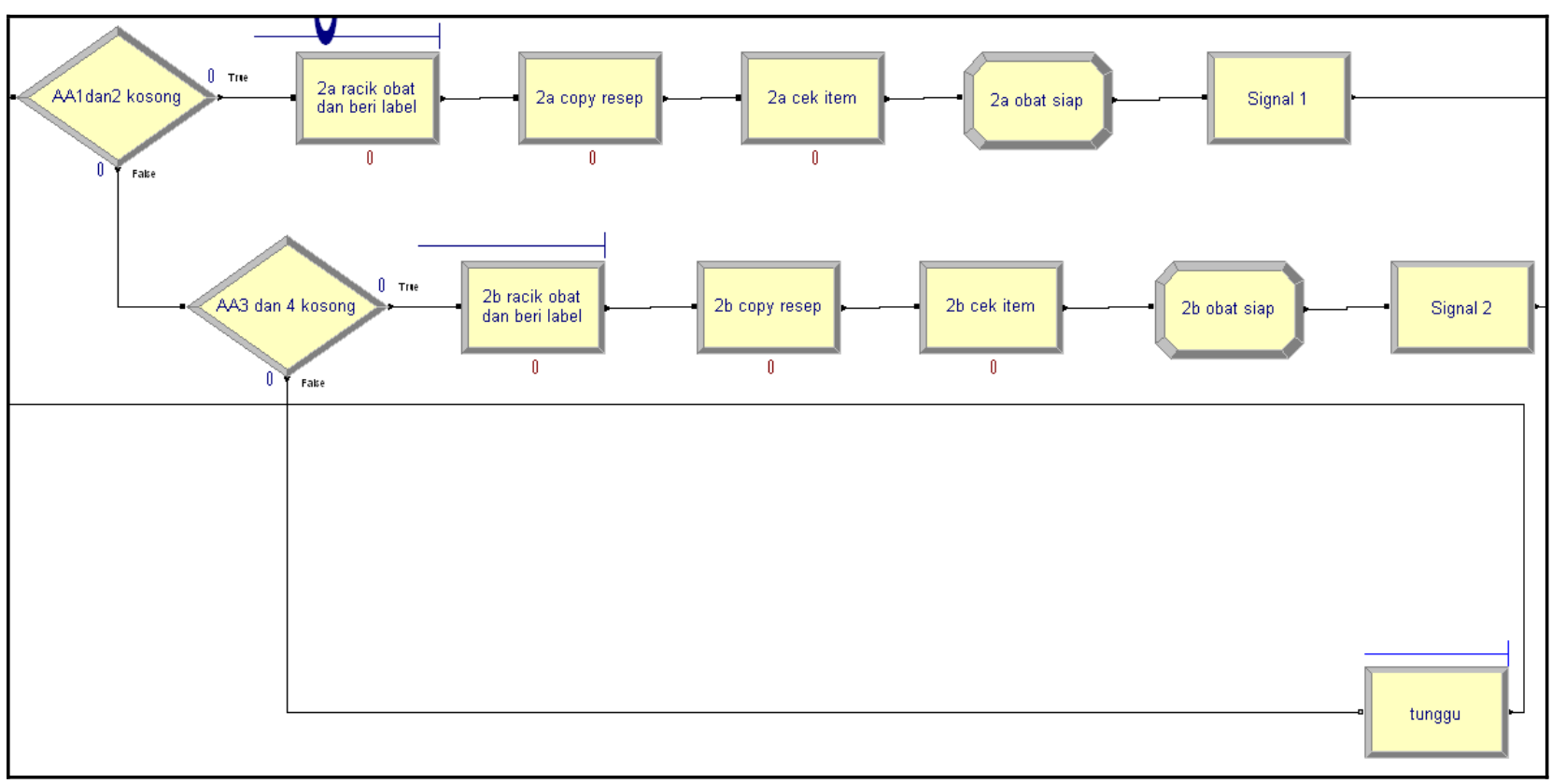

Gambar 5. Pemodelan Pelayanan Berdasarkan Kapasitas Operator 
Model simulasi ini juga mengggunakan modul assign yang digunakan untuk memberikan tambahan keterangan pada entitas. Pada beberapa penggunaan, modul assign digunakan untuk memberikan keterangan berupa attribute yang diberi nama pelayanan dengan nilai 1 dan entity picture berupa yellow page. Maka, setiap entitas yang telah melewati modul ini akan mendapatkan keterangan tambahan tersebut. Pada simulasi ini, juga dipakai modul route dan station untuk memudahkan pergerakan entitas. Modul route digunakan untuk memindahkan entitas ke station tertentu, sedangkan modul station digunakan sebagai penamaan tempat berlangsungnya proses tertentu. Untuk mengetahui kondisi operator, dilakukan animasi pada simulasi. Jika operator sedang busy, maka animasi akan berwarna merah, sedangkan jika sedang idle, maka animasi akan berwarna hijau. Secara keseluruhan, pemodelan untuk sistim pelayanan apotek existing dapat dilihat di Gambar 6.

Pada tahap verifikasi, diketahui bahwa tidak ada error ataupun warning dalam model sehingga model telah terverifikasi. Kemudian, dilakukan validasi terhadap model simulasi existing. Validasi dilakukan untuk menguji kesesuaian model simulasi existing dengan real system (Kelton, 2002). Pada permasalahan ini, validasi dilakukan dengan metode paired-t interval.

Hipotesa:

$H_{0}: \mu_{1}-\mu_{2}=0$

$H_{1}: \mu_{1}-\mu_{2} \neq 0$

$\alpha=0,05$

Tabel 1. Perhitungan Validasi dengan Metode Paired-t Interval

\begin{tabular}{|c|c|c|c|}
\hline Replikasi & Real System & Model Existing & Difference \\
\hline 1 & 61 & 58 & 3 \\
\hline 2 & 59 & 61 & -2 \\
\hline 3 & 55 & 62 & -7 \\
\hline 4 & 58 & 63 & -5 \\
\hline \multirow[t]{4}{*}{5} & 64 & 63 & 1 \\
\hline & Sampel mean & & -2 \\
\hline & Standart dev & & 4,123105626 \\
\hline & Variance & & 17 \\
\hline
\end{tabular}

$h w=\frac{\mathrm{t}_{5,0,025} \times 4,123105626}{\sqrt{5}}$

$h w=\frac{3,495406 \times 4,123105626}{\sqrt{5}}$

$h w=6,44521$

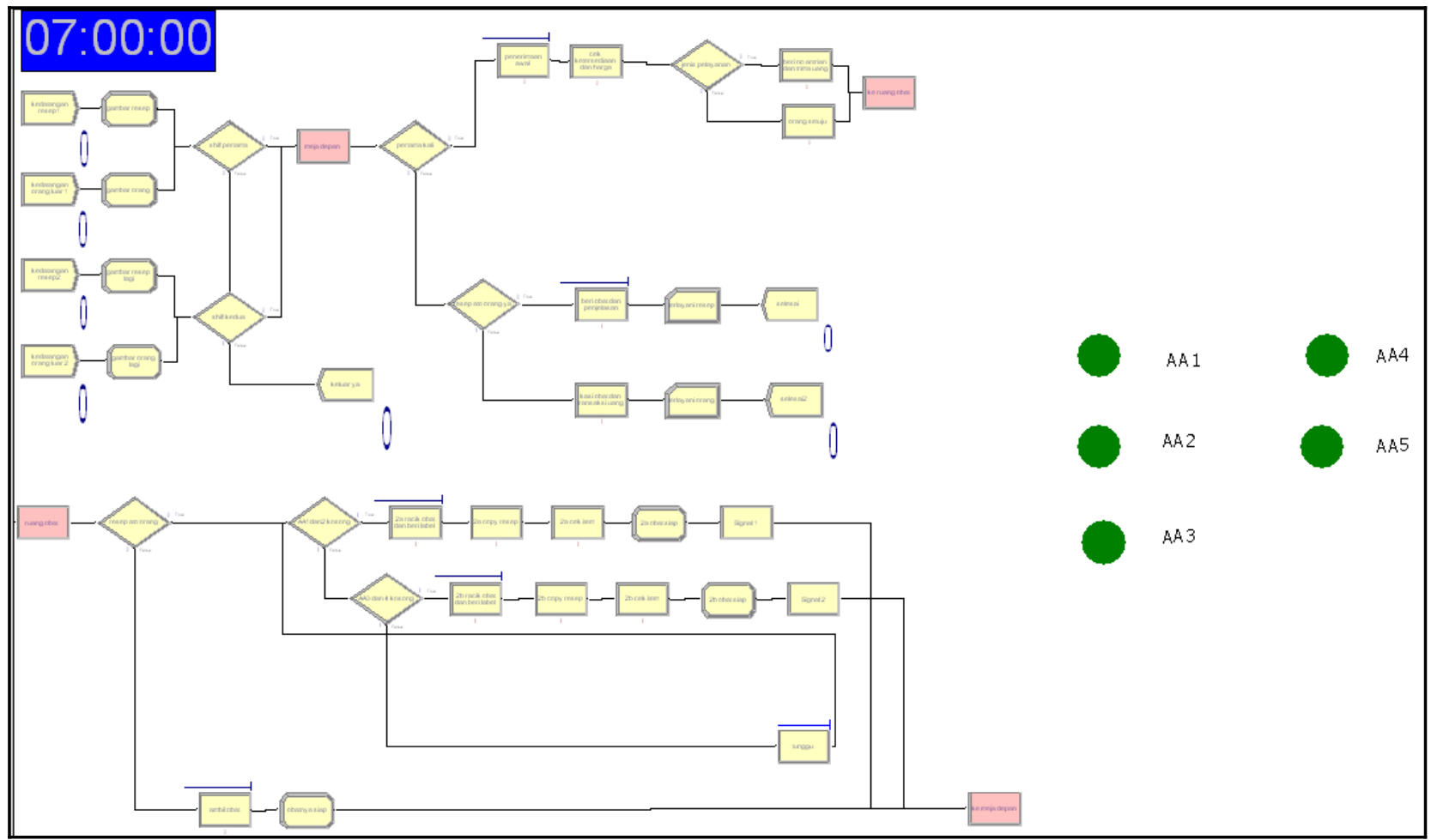

Gambar 6. Pemodelan Keseluruhan Sistim Existing 
Maka, 95\% confident interval-nya adalah

$\overline{\mathrm{X}}_{(1-2)}-\mathrm{hw} \leq \mu_{(1-2)} \leq \overline{\mathrm{X}}_{(1-2)}+\mathrm{hw}$

$-2-6,44521 \leq \mu_{(1-2)} \leq-2+6,44521$

$-8,44521 \leq \mu_{(1-2)} \leq 4,44521$

Karena nilai nol berada di antara rentang $\mu_{1}-\mu_{2}$, maka dapat dikatakan bahwa $\mu_{1}-\mu_{2}=0$. Keputusan yang diambil adalah terima $\mathrm{H}_{0}$ yang berarti model existing dan model yang dibuat di Arena tidak berbeda secara signifikan.

Karena model simulasi existing telah valid, skenario usulan dapat diterapkan. Pada skenario pertama, proses pelayanan dibagi menjadi tiga bagian, yaitu kelompok 1, yang terdiri atas mencatat info, membaca resep, mengecek ketersediaan dan menghitung harga, melakukan transaksi keuangan, dan memberikan nomor antrian; kelompok 2, yang terdiri atas membaca resep, mencatat sisa persediaan, meracik obat, memberi label etiket, meng-copy resep, mengecek item obat; serta kelompok 3, yang terdiri atas menjelaskan aturan pakai, melakukan transaksi keuangan, dan mencetak kuitansi. Masingmasing kelompok kerja dikerjakan oleh 4 operator, dan kelompok 1 dan kelompok 3 dilakukan oleh operator yang sama sehingga dibutuhkan 8 operator. Perbedaan model simulasi skenario usulan ini dengan model eksisting dimulai dari proses peracikan obat sampai dengan pengecekan item obat. Karena proses mengantri resep tidak lagi ditentukan berdasarkan kapasitas terpakai suatu operator, maka expression penentu keputusan pada decide sebelum proses peracikan obat berubah menjadi " 2 a racik obat dan beri label.WIP < 5", yang berarti entitas akan masuk ke proses tersebut ketika jumlah work in process-nya berjumlah kurang dari 5 (dengan kata lain, ketika masih ada operator yang idle). Pemodelan untuk kondisi ini digambarkan pada Gambar 7.

Pada skenario kedua, tidak dilakukan pengelompokan, akan tetapi penanganan entitas mulai dari proses awal hingga proses terakhir dikerjakan oleh 1 orang saja (1 operator). Perbedaan dengan skenario 1 terletak pada action yang digunakan pada setiap proses. Pada model ini, karena setiap 1 entitas ditangani oleh 1 operator mulai dari awal proses sampai akhir, maka action proses yang terletak di awal, yaitu penerimaan awal, adalah seize delay dan action proses yang terletak di akhir, yaitu "beri obat dan penjelasan" (untuk entitas resep) serta "kasih obat dan transaksi uang" (untuk entitas orang), adalah delay release. Sedangkan action pada proses-proses lainnya adalah delay. Selain itu, perbedaan juga terdapat pada jumlah operator yang diperlukan. Pada model ini, diperlukan 7 operator yang bekerja secara bergantian. Karena itulah, operator yang digunakan berbentuk set.

\section{Hasil Running Simulasi}

Running simulasi dilakukan sebanyak 5 kali. Hasil simulasi sistim existing, skenario 1, dan skenario 2 pada replikasi 1 digambarkan di Tabel 2.

Value added time menyatakan waktu yang terakumulasi ketika sebuah entitas mengalami proses yang dapat menambah nilainya. Pada hasil simulasi existing ini, rata-rata value added time resep sebesar 0,26198 jam atau sebesar 15,719 menit, sedangkan rata-rata value added time umum sebesar 0,041 jam atau sebesar 2,26 menit. Waiting time menyatakan waktu yang terakumulasi ketika suatu entitas mengantri untuk dilayani. Pada

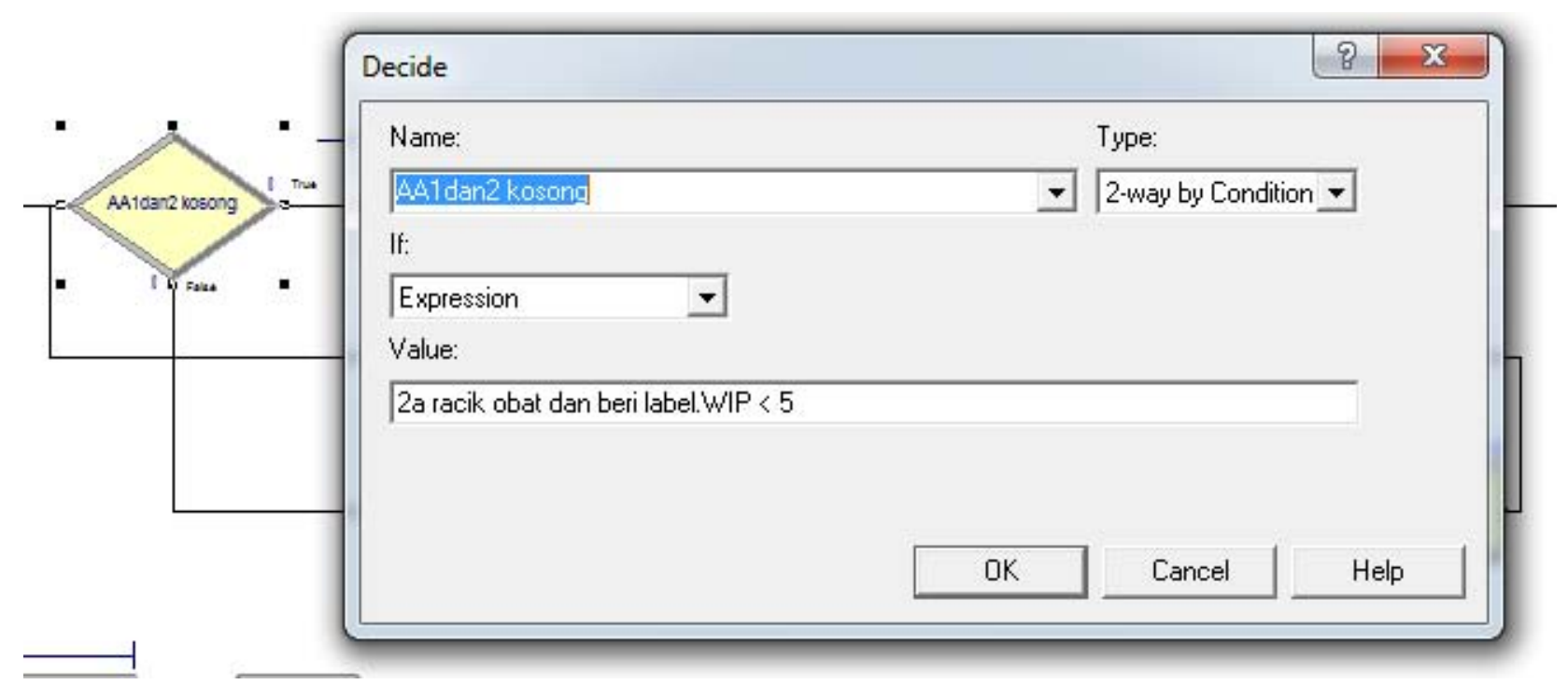

Gambar 7. Pemodelan Skenario 1 
Tabel 2. Rekapan Hasil Simulasi pada Replikasi 1

\begin{tabular}{lccc}
\hline Pembanding & Sistim Existing & Skenario 1 & Skenario 2 \\
\hline Value added time & (menit) & & \\
- pasien & 15,719 & 15,973 & 15,973 \\
- umum & 2,26 & 2,31 & 2,31 \\
Waiting time & 14.22 & 0 & 0 \\
(menit) & & & \\
Utilitas Operator & & & \\
- Operator 1 & 0,903 & 0,06 & 0,46 \\
- Operator 2 & 0,87 & 0,055 & 0,47 \\
- Operator 3 & 0,56 & 0,07 & 0,45 \\
- Operator 4 & 0,44 & 0,06 & 0,4 \\
- Operator 5 & 0,06 & 0,33 & 0,45 \\
- Operator 6 & -- & 0,32 & 0,48 \\
- Operator 7 & -- & 0,4 & 0,46 \\
- Operator 8 & -- & 0,37 & -- \\
Entity numbers in and out & & \\
- pasien & 90 & 97 & 97 \\
- umum & 30 & 30 & 30 \\
Entity terlayani & & & \\
- pasien & 58 & 62 & 62 \\
- umum & 18 & 17 & 17 \\
\hline
\end{tabular}

hasil simulasi eksisting ini, rata-rata waiting time konsumen (pasien) sebesar 0,23693 jam atau sebesar 14,22 menit. Selain itu, dapat diketahui bahwa utilitas operator 1 sebesar 0,903 ; operator 2 sebesar 0,87 ; operator 3 sebesar 0,56 ; operator 4 sebesar 0,44 ; dan operator 5 sebesar 0,06 . Perbedaan utilisasi ini menunjukkan adanya ketidakmerataan pekerjaan yang dilakukan oleh operator. Maka, perlu dilakukan perubahan pola pekerjaan untuk meratakan utilitas tiap operator.

Entity numbers in and out dan entity terlayani menunjukkan banyaknya entitas yang masuk, keluar, dan terlayani dalam sistim, baik pasien maupun umum. Pada simulasi model existing ini dapat diketahui bahwa terdapat 90 resep dan 30 umum yang masuk dan keluar dalam sistim, tetapi hanya 58 resep dan 18 orang umum yang terlayani oleh operator. Adanya perbedaan antara jumlah entitas yang keluar-masuk dan yang terlayani disebabkan karena digunakannya aturan shift. Jika modul create untuk shift 1 menghasilkan entitas pada saat shift 2 berlangsung, maka sistim pelayanan akan menolak entitas tersebut sehingga entitas langsung keluar dari sistim tanpa melalui proses pelayanan.

Pada hasil simulasi perbaikan skenario 1, ratarata value added time resep sebesar 0,26622 jam atau sebesar 15,973 menit, sedangkan rata-rata value added time umum sebesar 0,03851 jam atau sebesar 2,31 menit. Nilai tersebut sama persis dengan yang dihasilkan pada simulasi perbaikan skenario 2 . Hal yang juga harus diperhatikan adalah waiting time.
Pada hasil simulasi perbaikan skenario 1 dan 2, rata-rata waiting time konsumen sebesar 0 jam atau 0 menit, yang berarti, resep tidak perlu mengantri pada saat pelayanan peracikan obat. Dari segi pelayanan, memang terdapat sedikit peningkatan waktu pelayanan pada skenario perbaikan ini bila dibandingkan dengan keadaan sekarang, tetapi waktu tunggu resep berkurang secara signifikan.

Pada skenario 1, dapat diketahui bahwa utilitas operator 1 sebesar 0,06 ; operator 2 sebesar 0,055 ; operator 3 sebesar 0,07 ; operator 4 sebesar 0,06 ; operator 5 sebesar 0,33 ; operator 6 sebesar 0,32 ; operator 7 sebesar 0,4 ; dan operator 8 sebesar 0,37 . Nilai utilitas menunjukkan telah meratanya pembagian tugas dalam satu kelompok, akan tetapi antar kelompok 1 dan kelompok 2 masih terdapat perbedaan. Hal ini dikarenakan durasi pengerjaan tugas kelompok 2 cenderung lebih lama daripada kelompok 1. Pada skenario 2, dapat diketahui bahwa utilitas operator 1 sebesar 0,46 ; operator 2 sebesar 0,47 ; operator 3 sebesar 0,45 ; operator 4 sebesar 0,4 ; operator 5 sebesar 0,45 ; operator 6 sebesar 0,48 ; dan operator 7 sebesar 0,46 .

Pada simulasi model perbaikan 1 dan 2, dapat diketahui bahwa terdapat 97 resep dan 30 umum yang masuk dan keluar dalam sistim, tetapi hanya terdapat 62 resep dan 17 orang umum yang terlayani oleh operator. Sama dengan yang terjadi di simulasi eksisting, adanya perbedaan antara jumlah entitas yang keluar-masuk dan yang terlayani disebabkan karena digunakannya aturan shift. Jika modul create untuk shift 1 menghasilkan entitas pada saat shift 2 berlangsung, maka sistim pelayanan akan menolak entitas tersebut sehingga entitas langsung keluar dari sistim tanpa melalui proses pelayanan.

\section{Pemilihan Skenario Terbaik}

Pemilihan skenario terbaik dilakukan dengan membandingkan performansi antara model simulasi existing, model simulasi skenario usulan 1 , dan model simulasi skenario usulan 2. Performansi setiap sistim, baik sistim existing maupun sistim skenario usulan, dilihat dari lama waktu tunggu konsumen. Metode yang digunakan untuk membandingkan antara model eksisting dan model skenario 1 dan 2 adalah bonferroni approach (Robinson, 2004). Adapun hal yang dibandingkan adalah waktu tunggu konsumen (resep). Perhitungannya dapat dilihat pada Tabel 3. Hipotesa:

$$
\begin{aligned}
& H_{0}: \mu_{1}-\mu_{2}=\mu_{3} \\
& H_{1}: \mu_{1} \neq \mu_{2} \neq \mu_{3} \\
& \alpha=0,05
\end{aligned}
$$


Tabel 3. Perhitungan Comparing System dengan Metode Bonferoni

\begin{tabular}{|c|c|c|c|c|c|c|}
\hline Replikasi & Existing (A) & Skenario1 (B) & Skenario2 (C) & A-B & A-C & B-C \\
\hline 1 & 14,2158 & 0 & 0 & 14,215 & 14,215 & 0 \\
\hline 2 & 17,649 & 0 & 0 & 17,649 & 17,649 & 0 \\
\hline 3 & 16,509 & 0 & 0 & 16,509 & 16,509 & 0 \\
\hline 4 & 14,3316 & 0 & 0 & 14,331 & 14,331 & 0 \\
\hline 5 & 11,0598 & 0 & 0 & 11,059 & 11,059 & 0 \\
\hline \multicolumn{4}{|c|}{ Xbar } & 14,753 & 14,753 & 0 \\
\hline \multicolumn{4}{|c|}{ Stdev } & 2,528 & 2,528 & 0 \\
\hline
\end{tabular}

Perbandingan model eksisting dan model skenario 1

$$
\begin{aligned}
& h w=\frac{t_{4,0,0166} \times 2,528}{\sqrt{5}} \\
& h w=\frac{3,960787 \times 2,528}{\sqrt{5}} \\
& h w=4,479038
\end{aligned}
$$

Maka, 98,34\% confidence interval-nya adalah

$$
\overline{\mathrm{X}}_{(1-2)}-\mathrm{hw} \leq \mu_{(1-2)} \leq \overline{\mathrm{X}}_{(1-2)}+\mathrm{hw}
$$

$14,753-4,479038 \leq \mu_{(1-2)} \leq 14,75304+4,479038$

$$
10,274 \leq \mu_{(1-2)} \leq 19,2321
$$

Karena nilai nol berada di luar rentang $\mu_{(1-2)}$, maka tolak $\mathrm{H}_{0}$ sehingga sistim existing dan sistim skenario 1 berbeda secara signifikan.

Perbandingan model eksisting dan model skenario 2

$$
\begin{aligned}
& h w=\frac{t_{4,0,0166} \times 2,528}{\sqrt{5}} \\
& h w=\frac{3,960787 \times 2,528}{\sqrt{5}} \\
& h w=4,479038
\end{aligned}
$$

Maka, $98.34 \%$ confidence interval-nya adalah

$$
\mathrm{X}_{(1-3)}-\mathrm{hw} \leq \mu_{(1-3)} \leq \mathrm{X}_{(1-3)}+\mathrm{hw}
$$

$14,75304-4,479038 \leq \mu_{(1-3)} \leq 14,75304+4,479038$

$$
10,274 \leq \mu_{(1-3)} \leq 19,2321
$$

Karena nilai nol berada di luar rentang $\mu_{(1-3)}$, maka tolak $\mathrm{H}_{0}$ sehingga sistim existing dan skenario 2 berbeda secara signifikan.

Perbandingan model skenario 1 dan model skenario 2

$$
\begin{aligned}
& h w=\frac{t_{4,0,0166} \times 0}{\sqrt{5}} \\
& h w=\frac{3,960787 \times 0}{\sqrt{5}} \\
& h w=0
\end{aligned}
$$

Maka, 98.34\% confidence interval-nya adalah

$$
\begin{gathered}
\overline{\mathrm{x}}_{(2-3)}-\mathrm{hw} \leq \mu_{(2-3)} \leq \overline{\mathrm{X}}_{(2-3)}+\mathrm{hw} \\
0-0 \leq \mu_{(2-3)} \leq 0+0 \\
0 \leq \mu_{(2-3)} \leq 0
\end{gathered}
$$

Karena nilai nol berada di rentang $\mu_{(2-3)}$, maka terima $\mathrm{H}_{0}$ sehingga skenario 1 dan skenario 2 tidak berbeda secara signifikan.

Berdasarkan pengujian yang dilakukan, dihasilkan keputusan bahwa waktu tunggu pada skenario usulan 1 dan skenario usulan 2 menunjukkan perbedaan secara signifikan bila dibandingkan dengan waktu tunggu pada sistim existing yaitu sebesar 14,75 menit. Akan tetapi, tidak ada perbedaan secara signifikan antara waktu tunggu pada skenario 1 dan skenario 2 . Perbedaan antara skenario 1 dan 2 terletak pada jumlah operator yang dibutuhkan serta utilitas operator-operator tersebut. Operator pada skenario 1 berjumlah 8 orang, sedangkan pada skenario 2 berjumlah 7 orang. Utilitas operator pada skenario 2 cenderung lebih tinggi daripada utilitas operator di skenario 1. Selain itu, utilitas antar operator pada skenario 2 juga cenderung sama, sedangkan pada skenario 1, terdapat perbedaan antar operator pada kelompok kerja yang berbeda. Karena kedua skenario menghasilkan performansi yang sama, maka dapat diputuskan bahwa skenario 2 lebih baik daripada skenario 1 sebab jumlah operatornya lebih sedikit.

\section{SIMPULAN}

Berdasarkan penelitian yang telah dilakukan, maka jumlah operator yang optimal untuk apotek rumah sakit $\mathrm{X}$ adalah sesuai dengan skenario usulan 2 , yaitu 7 orang operator tanpa dilakukan pembagian kerja sehingga setiap 1 resep dilayani oleh 1 operator mulai dari penerimaan resep dari konsumen sampai penyerahan obat ke konsumen.

\section{DAFTAR PUSTAKA}

Kelton, D., 2002. Simulation with ARENA Second Edition. WCB McGraw Hill. New York. 
Khumairoh, L., 2009. Penentuan Jumlah Operator Optimal dengan Metode Workload Analysis pada Apotek RS $X$. Laporan Kerja Praktek Jurusan Teknik Industri ITS. Surabaya.

Partiwi, S. G., Gunarta, I. K, dan Hidayatullah, M., 2009. Evaluasi Kinerja Sistim Distribusi Perusahaan
Batubara dengan Adanya Penambahan Coal Terminal. Jurnal Teknik Industri, 10(2).

Robinson, S., 2004. Simulation: The Practice of Model Development and Use. John Willey \& Sons.

Siswanto, 2007. Operations Research. Penerbit Erlangga. Jakarta. 